\title{
Ragulator Complex Protein LAMTOR5
}

National Cancer Institute

\section{Source}

National Cancer Institute. Ragulator Complex Protein LAMTOR5. NCI Thesaurus. Code C118946.

Ragulator complex protein LAMT OR5 (91 aa, $10 \mathrm{kDa}$ ) is encoded by the human LAMT OR5 gene. This protein plays a role in both the modulation of mitogenic signaling and the down-regulation of hepatitis B virus replication. 